\title{
Estimating the amount of water required to extinguish wildfires under different conditions and in various fuel types
}

\author{
Rickard Hansen \\ Mälardalen University, Box 833, SE-721 23 Västerås, Sweden. \\ Email: rickard.hansen@mdh.se
}

\begin{abstract}
In wildland fires where water is used as the primary extinguishing agent, one of the issues of wildfire suppression is estimating how much water is required to extinguish a certain section of the fire. In order to use easily distinguished and available indicators, the flame length and the area of the active combustion zone were chosen as suitable for the modelling of extinguishing requirements. Using Byram's and Thomas' equations, the heat release rate per unit length of fire front was calculated for low-intensity surface fires, fires with higher wind conditions, fires in steep terrain and high-intensity crown fires. Based on the heat release rate per unit length of fire front, the critical water flow rate was calculated for the various cases. Further, the required amount of water for a specific active combustion zone area was calculated for various fuel models. Finally, the results for low-intensity surface fires were validated against fire experiments. The calculated volumes of water can be used both during the preparatory planning for incidents as well as during firefighting operations.
\end{abstract}

Additional keywords: active combustion zone, critical water application rate, fire point theory, flame length, suppression.

Received 5 February 2011, accepted 27 November 2011, published online 1 June 2012

\section{Introduction}

An important aim of wildfire research is developing tools for suppression decisions. One area in which better decision tools are needed is for estimating how much water is required for extinguishing fires as a function of fuel type and fire behaviour characteristics.

There is little research on water requirements for fire suppression. Stechishen (1970) and Stechishen and Little (1971) used a spray rig with a nozzle arrangement to water uniformly across a fuel bed. They developed equations relating the penetration depth of the water into the fuel bed required to extinguish the fire to fire intensity. Loane and Gould (1986) used experimental data from aerial drops on fires in various fuels, small-scale laboratory experiments and field studies to develop equations to calculate the depth of water required for fire suppression as a function of fire intensity.

Douglas (1973) estimated a minimum water flow requirement per metre of fireline as $10-20 \mathrm{~L} \mathrm{~min}^{-1}$ for surface fires in south-eastern Australian pine forests. These estimates were apparently based on expert opinion. Andrews and Rothermel (1982) and Alexander (2000) used flame length and fireline intensity to determine the appropriate fire suppression activities. Alexander stated that suppression using pressurised water is an appropriate action for fireline intensities up to $2000 \mathrm{~kW} \mathrm{~m}^{-1}$.

Other studies have evaluated the water demand for extinguishing fires in wood cribs (O'Dougherty and Young 1965; Kung and Hill 1975; Tamanini 1976) and the required water density of sprinkler systems for various types of commodities.
Although these represent different types of fuel beds from wildfire fuels, the importance of the mixture of air and fuel in fuel and basic combustion theory, heat transfer theory, etc., will be the same for a wood crib fire or a wildfire in a fuel bed with pine needles.

This paper presents a methodology for determining the required amount of water for a wildfire in various fuel types based on observations of flame length and the size of the active combustion zone.

\section{Heat release rate of the fire front}

Byram (1959) developed a series of fire equations that were based on a field study in a single fuel type. Byram defined fireline intensity as the heat release rate per unit length of the fire front. He proposed the following equation for fireline intensity $\left(I, \mathrm{~kW} \mathrm{~m}^{-1}\right)$ :

$$
I=H \times w \times r
$$

where $H$ is the heat of combustion $\left(\mathrm{kJ} \mathrm{kg}^{-1}\right) ; w$ is the mass of the available fuel per unit area $\left(\mathrm{kg} \mathrm{m}^{-2}\right)$ and $r$ is the rate of spread $\left(\mathrm{m} \mathrm{min}^{-1}\right)$.

The heat of combustion value used in Eqn 1 is a net value where both the latent heat absorbed when the water of reaction is vaporised and the calorific effect of fuel moisture content are subtracted. Byram also made reductions due to radiation and incomplete combustion. As Alexander (1982) points out, there are arguments against making the latter two 
reductions; for example, that radiation should not be considered as a simple loss but as an important factor with respect to the fire behaviour. Alexander (1982) states that it is almost impossibleunder field conditions - to exactly determine the amount of fuel consumed in the combustion zone. The amount of fuel consumed by combustion and residual burning after the passage of the fire front will increase the mass of available fuel per unit area $(w)$ and cause an overestimation of the fireline intensity.

Byram presented an approximate relation between the flame length and the fireline intensity:

$$
L_{\mathrm{f}}=0.0775 \times I^{0.46}
$$

where $L_{\mathrm{f}}$ is the flame length $(\mathrm{m})$. Eqn 2 is based on the assumption that the fire front is a long straight line and of constant fire intensity. Eqn 2 can be transformed into the following, expressing the fireline intensity in terms of the flame length:

$$
I=259.833 \times L_{\mathrm{f}}^{2.174}
$$

Byram's equations are useful when correlating flame characteristics with fire behaviour, but must not be used to compare fire behaviour in different fuel types as the fire behaviour can differ depending on fuel structure.

There have in the past been concerns over the use of the term fire intensity (Tangren 1976). Throughout the rest of this paper, we use the term heat release rate per unit length of fire front instead to emphasise the connection to the heat release rate of the fire.

A practical advantage of using the flame length to estimate the heat release rate of the fire front is that the flame length is easy to observe in the field, whereas the heat release rate of the fire front is difficult to measure directly. The flame length is defined as the distance between the flame tip and the ground.

Despite the weaknesses of the Byram equations, they are widely used among fire practitioners and have shown reasonably good agreement with field experiments (Van Wagner 1968; Thomas 1971; Sneeuwjagt and Frandsen 1977). We will use them in this paper together with Thomas' equation when quantifying the heat release rate per unit length of fire front.

\section{Extinguishing with water - low-intensity surface fires}

Water is widely used as an extinguishing medium in wildfire operations, both for suppressing the fire and for retarding fire spread. The advantages of water as an extinguishing medium are its cooling effects, low cost and the accessibility of water sources on the landscape.

The application of water to a wildfire can generally be divided into three different modes:

1. Water applied into the flames. In this case, extinguishment will occur through the cooling of the flames to a flame temperature below the critical value.

2. Water applied to the burning fuel surface. Extinguishment will occur through the cooling of the fuel, resulting in a reduced pyrolysis rate and quenching of the flames.

3. Water applied to fuel surfaces not yet involved in the fire. Extinguishment will occur through starvation as the fuel ahead of the fire is prevented from beginning to pyrolyse, cutting off the production of combustion gases.

Fire Point Theory (Rasbash 1986; Beyler 1992), accounting only for surface cooling, would be appropriate for wildfire situations as the effect of the evaporated water and other gasphase effects are neglected. As the fire is not enclosed, the water vapour is dispersed and will not have an inert effect on the fire, making the assumption valid. The Fire Point Theory is based on an assumption of essentially steady-state conditions. The energy balance at the fuel surface when water is applied can be expressed as:

$$
\left(f \times \Delta H_{\mathrm{c}}-L_{\mathrm{v}}\right) \times \dot{m}^{\prime \prime}+\dot{q}_{\mathrm{E}}^{\prime \prime}-\dot{q}_{\mathrm{L}}^{\prime \prime}-\dot{q}_{\mathrm{water}}^{\prime \prime}=0
$$

where $f$ is the heat release fraction transferred back to the fuel surface by convection and radiation; $\Delta H_{\mathrm{c}}$ is the effective heat of combustion $\left(\mathrm{kJ} \mathrm{kg}^{-1}\right)$, which is set to $17900 \mathrm{~kJ} \mathrm{~kg}^{-1}$ for a pineneedle fuel bed (Madrigal et al. 2009); $L_{\mathrm{V}}$ is the heat of gasification of the fuel $\left(\mathrm{kJ} \mathrm{kg}^{-1}\right)$, which is set to $1800 \mathrm{~kJ} \mathrm{~kg}^{-1}$ for organic fuels (Tewarson 2002); $\dot{m}^{\prime \prime}$ is the mass burning rate per unit fuel area $\left(\mathrm{kg} \mathrm{m}^{-2} \mathrm{~s}^{-1}\right)$; $\dot{q}_{\mathrm{E}}^{\prime \prime}$ is the external heat flux $\left(\mathrm{kW} \mathrm{m}^{-2}\right) ; \dot{q}_{\mathrm{L}}^{\prime \prime}$ is the heat loss from the surface $\left(\mathrm{kW} \mathrm{m}^{-2}\right)$ and $\dot{q}_{\text {water }}^{\prime \prime}$ is the heat loss due to water vaporisation $\left(\mathrm{kW} \mathrm{m}^{-2}\right)$.

The mass burning rate at the critical point can be described using Spalding's B Number Theory (Spalding 1955):

$$
\dot{m}_{\mathrm{cr}}^{\prime \prime}=\frac{h}{c_{\mathrm{p}}} \times \ln \left(1+B_{\mathrm{cr}}\right)=\frac{h}{c_{\mathrm{p}}} \times \ln \left(1+\frac{Y_{\mathrm{O}_{2}} \times \Delta H_{\mathrm{R}, \mathrm{O}_{2}}}{\phi \times \Delta H_{\mathrm{c}}}\right)
$$

where $h$ is the convective heat transfer coefficient $\left(\mathrm{W} \mathrm{m}^{-2} \mathrm{~K}\right)$, which is set to $20 \mathrm{~W} \mathrm{~m}^{-2} \mathrm{~K}$ assuming natural convection (Silvani and Morandini 2009). The convective heat transfer coefficient is an average value based on field experiments with different types of vegetation and various wind speeds and slopes using data from heat flux sensors assuming the shape of a flat plate. $c_{\mathrm{p}}$ is the specific heat of air at constant pressure $\left(\mathrm{kJ} \mathrm{kg}^{-1} \mathrm{~K}^{-1}\right)$, which is set to $1.0 \mathrm{~kJ} \mathrm{~kg}^{-1} \mathrm{~K}^{-1} ; B_{\text {cr }}$ is the $\mathrm{B}$ number at extinguishment; $Y_{\mathrm{O}_{2}}$ is the oxygen mass fraction, which is set to 0.233 and $\Delta H_{\mathrm{R}, \mathrm{O}_{2}}$ is the heat of combustion per unit mass of oxygen consumed $\left(\mathrm{kJ} \mathrm{kg}^{-1}\right)$, which is set to $13980 \mathrm{~kJ} \mathrm{~kg}^{-1}$ for a fuel bed of Pinus pinaster needles (Santoni et al. 2010). The value was based on a fire experiment on a platform with no slope and no wind. $\phi$ is the fractional convective heat loss from the flame required for quenching the flame, which is set to 0.3 (Rasbash 1975).

Setting $\dot{m}^{\prime \prime}=\dot{m}_{\mathrm{cr}}^{\prime \prime}$ to find the properties at extinguishment, we obtain the fire point equation (at the critical mass loss rate, $f=\phi)$ :

$$
\begin{aligned}
(\phi \times & \left.\Delta H_{\mathrm{c}}-L_{\mathrm{v}}\right) \times\left(\frac{h}{c_{\mathrm{p}}} \times \ln \left(1+\frac{Y_{\mathrm{O}_{2}} \times \Delta H_{\mathrm{R}, \mathrm{O}_{2}}}{\phi \times \Delta H_{\mathrm{c}}}\right)\right) \\
+ & \dot{q}_{\mathrm{E}}^{\prime \prime}-\dot{q}_{\mathrm{L}}^{\prime \prime}-\dot{q}_{\text {water }}^{\prime \prime}=0
\end{aligned}
$$

The heat loss due to the vaporisation of water $\left(\dot{q}_{\text {water }}^{\prime \prime}\right)$ is:

$$
\dot{q}_{\text {water }}^{\prime \prime}=\eta_{\text {water }} \times \dot{m}_{\text {water,cr }}^{\prime \prime} \times L_{\mathrm{v}, \text { water }}
$$


where $\eta_{\text {water }}$ is the efficiency of water application; $L_{\mathrm{v}, \text { water }}$ is the enthalpy change of water at $283 \mathrm{~K}$ and water vapour at $373 \mathrm{~K}$ $\left(\mathrm{kJ} \mathrm{kg}^{-1}\right)$ and $\dot{m}_{\text {water,cr }}^{\prime \prime}$ is the critical water application rate $\left(\mathrm{kg} \mathrm{m}^{-2} \mathrm{~s}^{-1}\right)$. Combining this with the fire point equation results in:

$$
\dot{m}_{\text {water,cr }}^{\prime \prime}=\dot{m}_{\text {water }, \mathrm{cr}, 0}^{\prime \prime}+\frac{\dot{q}_{\mathrm{E}}^{\prime \prime}}{\eta_{\text {water }} \times L_{\mathrm{v}, \text { water }}}
$$

where $\dot{m}_{\text {water.cr.0 }}^{\prime \prime}$ is the critical water application rate with no external heat flux $\left(\mathrm{kg} \mathrm{m}^{-2} \mathrm{~s}^{-1}\right)$, i.e.:

$$
\dot{m}_{\text {water }, \mathrm{cr}, 0}^{\prime \prime}=\frac{\left(\varphi \times \Delta H_{\mathrm{c}}-L_{\mathrm{v}}\right) \times\left(\frac{h}{c_{\mathrm{p}}} \times \ln \left(1+\frac{Y_{\mathrm{O}_{2}} \times \Delta H_{\mathrm{R}, \mathrm{O}_{2}}}{\phi \times \Delta H_{\mathrm{c}}}\right)\right)-\dot{q}_{\mathrm{L}}^{\prime \prime}}{\eta_{\text {water }} \times L_{\mathrm{v}, \text { water }}}
$$

The minimum heat flux that will sustain a fire is given by:

$$
\dot{q}_{\mathrm{E}, 0}^{\prime \prime}=\dot{m}_{\text {water,cr }, 0}^{\prime \prime} \times \eta_{\text {water }} \times L_{\mathrm{v}, \text { water }}
$$

Regarding the heat loss from the surface $\left(\dot{q}_{\mathrm{L}}^{\prime \prime}\right)$, the conductive heat losses are neglected as the radiative and convective heat losses will dominate. The convective heat loss is given by:

$$
\dot{q}_{\mathrm{L}, \mathrm{conv}}^{\prime \prime}=h \times \Delta T
$$

where $\Delta T$ is the temperature difference between the fuel surface and the surrounding air $(\mathrm{K})$. The fuel surface temperature is set to $588 \mathrm{~K}$, which is the ignition temperature for a pine-needle fuel bed (Torero and Simeoni 2010). The ignition temperature is an average of values found in the literature. The ambient temperature is set to $293 \mathrm{~K}$, resulting in a convective heat loss of $6 \mathrm{~kW} \mathrm{~m}^{-2}$.

The radiative heat loss is:

$$
\dot{q}_{\mathrm{L}, \text { rad }}^{\prime \prime}=\varepsilon \times \sigma \times\left(T_{\text {fuel }}^{4}-T_{\mathrm{a}}^{4}\right)
$$

where $\varepsilon$ is the fuel emissivity, which is set to 0.6 (Malbi 2001), and was obtained through grass-fire experiments with no slope and no wind. $\sigma$ is the Stefan-Boltzmann constant $\left(5.67 \times 10^{-8}\right.$ $\left.\mathrm{W} \mathrm{m}{ }^{-2} \mathrm{~K}^{-4}\right) ; T_{\text {fuel }}$ is the fuel surface temperature and $T_{\mathrm{a}}$ is the ambient temperature. This results in a radiative heat loss of $4 \mathrm{~kW} \mathrm{~m}^{-2}$ and the total surface heat loss is $10 \mathrm{~kW} \mathrm{~m}^{-2}$.

Assuming that $\eta_{\text {water }}$ is equal to 0.7 , a somewhat conservative value for the water demand, and the enthalpy change of water is equal to $2.64 \times 10^{3} \mathrm{~kJ} \mathrm{~kg}^{-1}$, the following critical water application rate with no external heat flux $\left(\dot{m}_{\text {water.cr. } 0}^{\prime \prime}, \mathrm{kg} \mathrm{m}^{-2} \mathrm{~s}^{-1}\right)$ is calculated:

$$
\dot{m}_{\text {water, }, \mathrm{r}, 0}^{\prime \prime} \approx 12.9 \times 10^{-3}
$$

When calculating the external heat flux, it is assumed that flame radiation will dominate and other components will not be accounted for. This assumption is valid for low-wind conditions (Weber 1989).

The flame length will vary along the fireline and therefore the highest flame length observed should be used in a conservative approach. The flame is considered to be three-sided with a rectangular shape (the front, rear and upper part of the active combustion zone). The incident flame radiation per unit area is given by:

$$
\dot{q}_{\mathrm{f}}^{\prime \prime}=\frac{\dot{Q}_{\mathrm{r}}^{\prime}}{\left(2 \times L_{\mathrm{f}}+D\right)} \times \phi \times \tau
$$

where $\dot{Q}_{\mathrm{r}}^{\prime}$ is the radiative component per unit length of fire front of the total heat release rate $\left(\mathrm{kW} \mathrm{m}^{-1}\right) ; \varphi$ is the view factor assumed to be 1 owing to the close proximity of the unburned fuel with respect to the flames of the fire front and as a conservative approach; $\tau$ is atmospheric transmissivity - which is similarly assumed to be $1 ; D$ is the depth of the active combustion zone $(\mathrm{m})$.

The radiative component per unit length of fire front is assumed to be $27 \%$ (Tihay et al. 2009) - extracted from a fire experiment with a bed of crushed pine needles. The heat release rate per unit length of fire front $(I)$ was calculated yielding:

$$
\dot{q}_{\mathrm{f}}^{\prime \prime}=\frac{0.27 \times I}{\left(2 \times L_{\mathrm{f}}+D\right)} \times \phi \times \tau
$$

Assuming that:

$$
\dot{q}_{\mathrm{f}}^{\prime \prime}=\dot{q}_{\mathrm{E}}^{\prime \prime}
$$

the critical water application rate can be plotted as a function of the flame length.

The depth of the active combustion zone was calculated using (Alexander 1982):

$$
D=\frac{I}{I_{\mathrm{R}}}(\mathrm{m})
$$

where $I_{\mathrm{R}}$ is the heat release rate per unit area in the active combustion zone $\left(\mathrm{kW} \mathrm{m}^{-2}\right)$.

In Fig. 1, the critical water flow rate is plotted where the heat release rate per unit area in the active combustion zone was assumed to be steady-state at $500 \mathrm{~kW} \mathrm{~m}^{-2}$.

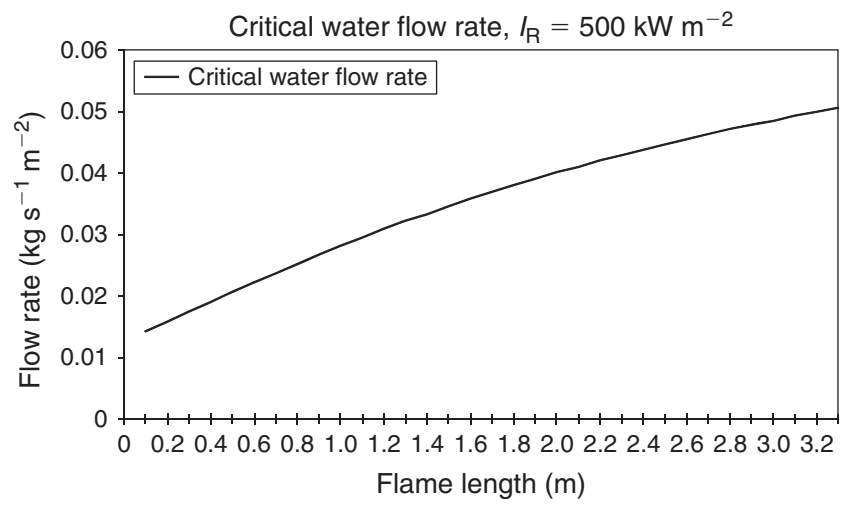

Fig. 1. Critical water application rate as a function of the flame length. The heat release rate per unit area in the active combustion zone is set constant at $500 \mathrm{~kW} \mathrm{~m}^{-2}$. 


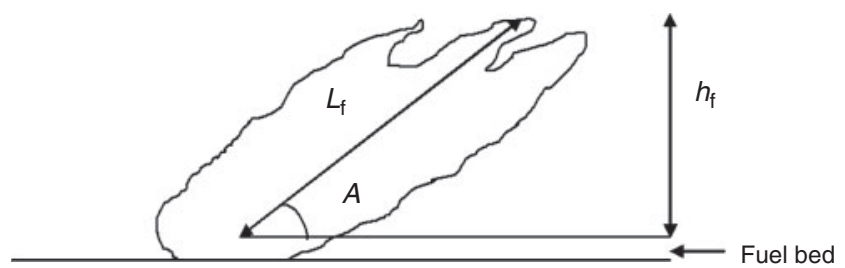

Fig. 2. The different characteristics of a flame: flame length $\left(L_{\mathrm{f}}\right)$, flame angle $(A)$ and flame height $\left(h_{\mathrm{f}}\right)$.

The methodology presented uses the flame length as a key input parameter. As Johnson (1982) points out, there are difficulties estimating flame length at a wildfire as the flame length will vary along the fire front owing to differences in fuel situation, topography, etc. This problem may be partially overcome by using the largest flame length observed, applying a conservative approach, thereby minimising the effect of fluctuating flame length.

Several inexact assumptions have been made in the previous as well as in the following calculations; the values were used in the calculations as no other value was found in the literature.

\section{Accounting for higher wind conditions, topography and high-intensity fires}

The methodology presented applies to low-intensity surface fires. In cases of high-intensity fires, fires with higher wind conditions or in steep terrain, the external heat flux will have to be adjusted as the convective heat transfer has to be accounted for in some cases and Thomas' equation used when calculating the heat release rate per unit length of fire front for high-intensity fires.

At very low wind speeds in flat terrain, the angle between the flame and the unburned fuel ahead - defined as the flame angle will be $90^{\circ}$ (Alexander 1982). As the wind speed increases, the flame angle decreases. Eqn 17 could be used for the relationship between wind speed and the tilt angle ( $\alpha$, degrees) from the vertical of the front of the flame (Albini 1981):

$$
\tan ^{2}(\alpha)=\frac{3 \times U^{2}}{2 \times g \times H_{\mathrm{f}}}
$$

where $U\left(\mathrm{~m} \mathrm{~s}^{-1}\right)$ is the mean horizontal wind speed; $H_{\mathrm{f}}(\mathrm{m})$ is the flame tip height and $g$ is the acceleration due to gravity $\left(\mathrm{m} \mathrm{s}^{-2}\right)$.

The following equation is used when calculating the windaffected flame length (m):

$$
L_{\mathrm{f}}=\frac{h_{\mathrm{f}}}{\sin (A)}
$$

where $A$ is the flame angle (degrees) and $h_{\mathrm{f}}$ is the flame height (m). Please see Fig. 2 for a depiction of the parameters.

The relationship between the tilt angle and the flame angle (degrees) is:

$$
\alpha=90-A
$$

When the flame angle is lower than $30^{\circ}$, the flames no longer rise from the fuel bed but linger along the surface and convection has to be accounted for (Chandler et al. 1983).
The convective heating per unit area can then be calculated:

$$
\dot{q}_{\text {conv }}^{\prime \prime}=h \times\left(T_{\mathrm{g}}-T_{\text {fuel }}\right)
$$

where $T_{\mathrm{g}}$ is the gas temperature $(\mathrm{K})$.

When accounting for convection, the external heat flux $\left(\dot{q}_{\mathrm{E}}^{\prime \prime}\right)$ is calculated using:

$$
\dot{q}_{\mathrm{E}}^{\prime \prime}=\dot{q}_{\mathrm{f}}^{\prime \prime}+\dot{q}_{\mathrm{conv}}^{\prime \prime}
$$

In the following calculations, the gas temperature was assumed to be $800 \mathrm{~K}$ (the flame-tip temperature). The convective heat transfer coefficient was set to $77 \mathrm{~W} \mathrm{~m}^{-2} \mathrm{~K}$, assuming forced convection and air velocity at $10 \mathrm{~m} \mathrm{~s}^{-1}$ (Silvani and Morandini 2009). In Fig. 3, the critical flow rate for a wind velocity of $10 \mathrm{~m} \mathrm{~s}^{-1}$ is displayed. The heat release rate per unit area was assumed to be steady-state at $500 \mathrm{~kW} \mathrm{~m}^{-2}$. This is a rough assumption but was made to simplify the calculations, focussing on the methodology.

When accounting for topography, convection has to be included as for the wind case and the crown-fire case. Convective heating has to be accounted for in cases of zero or near-zero wind conditions when the fire is burning up a slope of at least $30^{\circ}$ (Butler et al. 2004). In Fig. 3, the critical flow rate at a slope of more than $30^{\circ}$ and zero-wind conditions - assuming natural convection - is displayed. The heat-release rate per unit area was assumed to be steady-state at $500 \mathrm{~kW} \mathrm{~m}^{-2}$. The convective heat transfer coefficient was assumed to be higher than for the noslope case (Silvani and Morandini 2009): $25 \mathrm{~W} \mathrm{~m}^{-2} \mathrm{~K}$.

Eqn 2 is well suited to low-intensity surface fires; with respect to fires with higher heat release rates per unit length of fire front - such as crown fires - Thomas' equation is better suited (Thomas 1963):

$$
L_{\mathrm{f}}=0.0266 \times I^{0.667}
$$

Thomas' equation was developed for flames from an infinite strip source and is widely used in wildfire applications. Highintensity fires are assumed where the flame length exceeds $3.3 \mathrm{~m}$ (Rothermel 1991).

Van Wagner (1977) states that radiant heat transfer and convective heat transfer play a major role in crown fire spread. Albini (1985) has presented arguments concluding that convective cooling and radiation heat losses occur in the fuels ahead during a crown fire.

Albini (1966) also states that in cases of fire spreading up steep slopes and in high-wind situations, convective heat transfer also has to be accounted for. But the fire plume momentum could overcome the tilting effect of the wind and in those cases, only radiative heat transfer to the fuel ahead should be accounted for (Albini 1985).

When accounting for the wind effect during crown fires, the following equation should be used when calculating the wind speed at the top of the forest canopy $\left(\mathrm{m} \mathrm{s}^{-1}\right)$ (Butler et al. 2004):

$$
U_{\mathrm{c}}=\frac{U_{10}}{3.6 \times\left[1+\ln \left(1+\frac{28}{H_{\mathrm{t}}}\right)\right]}
$$




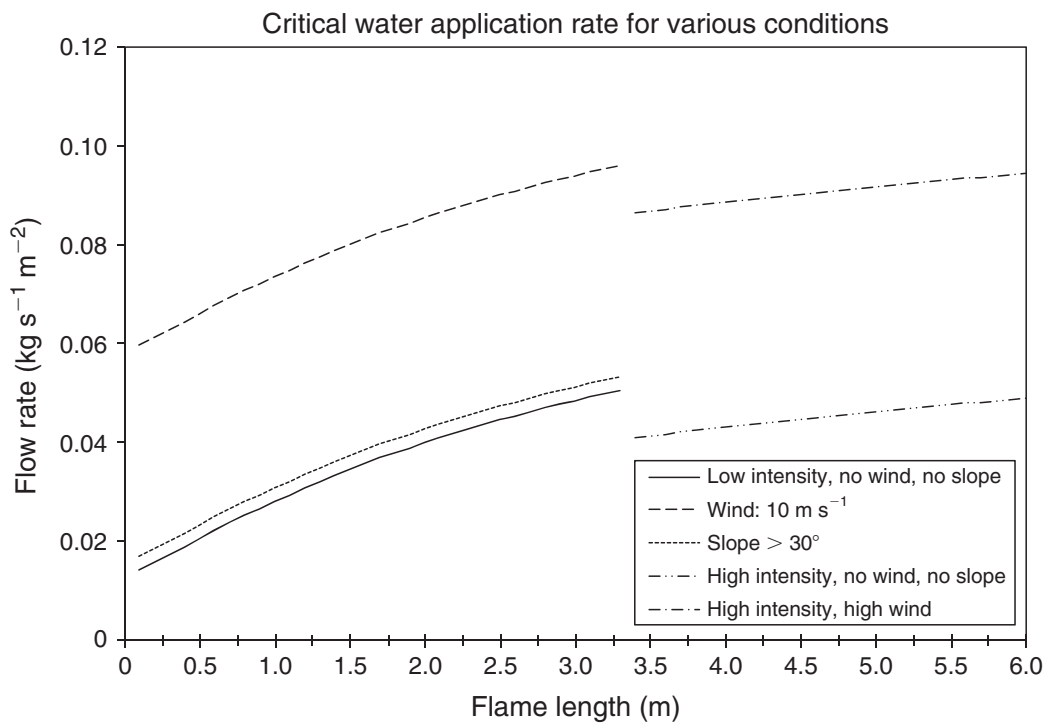

Fig. 3. Critical water application rate - as a function of the flame length - for various conditions: low intensity, no wind and no slope; wind at $10 \mathrm{~m} \mathrm{~s}^{-1}$; slope more than $30^{\circ}$; high intensity, no wind and no slope; high intensity and high wind.

where $U_{10}$ is the wind speed at a height of $10 \mathrm{~m}$ in the open $\left(\mathrm{km} \mathrm{h}^{-1}\right)$ and $H_{\mathrm{t}}$ is the forest canopy height $(\mathrm{m})$.

The flame length can be calculated using Eqns 17-19. The tilt angle and flame length are the primary factors affecting heat transfer to the fuel ahead.

In Fig. 3, the critical water flow rates for high-intensity fires at zero-wind conditions and high-wind conditions $\left(10 \mathrm{~m} \mathrm{~s}^{-1}\right)$ respectively are displayed. The heat-release rate per unit area was assumed to be steady-state at $2000 \mathrm{~kW} \mathrm{~m}^{-2}$.

When examining the critical water application rate for highintensity fires, windy conditions and steep terrain, it can be seen that the wind conditions have the largest effect. This is probably due to the fact that high-wind conditions will imply convective heating and a higher convective heat transfer coefficient due to forced convection, resulting in higher water demands.

\section{Duration of water application}

In calculating the total amount of water required to extinguish a wildfire, the duration of water application has to be accounted for and multiplied by the water application rate. Thomas (1957) and Baldwin (1970) present studies regarding the required duration of water application for fires in buildings but as no studies were found regarding wildfires, their results have been used in the following calculations. Both studies are based on statistical data from fire departments and the duration of water application is determined as a function of the fire area. Baldwin (1970) presents the following two equations:

$$
\begin{aligned}
& t=100 \times A_{\text {fire }}^{0.559} \\
& t=198 \times A_{\text {fire }}^{0.5}
\end{aligned}
$$

where $t$ is the duration of water application (s) and $A_{\text {fire }}$ is the fire area $\left(\mathrm{m}^{2}\right)$. Note that Eqn 24 is valid for fire areas over $20 \mathrm{~m}^{2}$ and Eqn 25 for fire areas over $200 \mathrm{~m}^{2}$.
Applying Eqn 24 to a fire area of 20 and $100 \mathrm{~m}^{2}$, and Eqn 25 to a fire area of $200 \mathrm{~m}^{2}$, the total water amount could be calculated for low-intensity surface fires using Byram's equation, and for high-intensity fires using Thomas' equation (the heat release rate per unit area was assumed to be steady-state at 500 and $2000 \mathrm{~kW} \mathrm{~m}^{-2}$ respectively); see Fig. 4.

As noted when comparing the graphs in Fig. 4, there is a distinct increase in the amount of water for the low-intensity case whereas for the high-intensity case, the increase has levelled off. This is due to the nature of Byram's and Thomas' equations, as the heat release rate per unit length of fire front will increase for lower flame lengths and level off for higher flame lengths.

Thomas (1957) and Baldwin (1970) use fire area as a parameter and owing to the enclosed nature of buildings, the fire area can be the total area of the building. In the case of wildfires, the total fire area should not be used when calculating the amount of water required; only the area of the active combustion zone should be used, as the fire activity in the burned area will be considerably less than in the active combustion zone, with very small flames or none at all. The burned area will play a minor role during the initial suppression operations until the start of the mop-up operations.

Factors such as the level of experience of the firefighter and applied nozzle technique will have an effect on the amount of water used-i.e. $\eta_{\text {water }}$. Therefore, such operational aspects must be considered when determining the required amount of water. As in the cases presented by Baldwin (1970), a statistical approach is suggested when accounting for operational aspects.

\section{The amount of water for different fuel models}

Anderson (1982) presents flame lengths for the 13 fuel models of Rothermel (1972) and Albini (1976). The flame lengths are presented in Table 1, corresponding to a low wind speed of $2.2 \mathrm{~m} \mathrm{~s}^{-1}$ and a moisture content of $8 \%$ (a live fuel moisture 


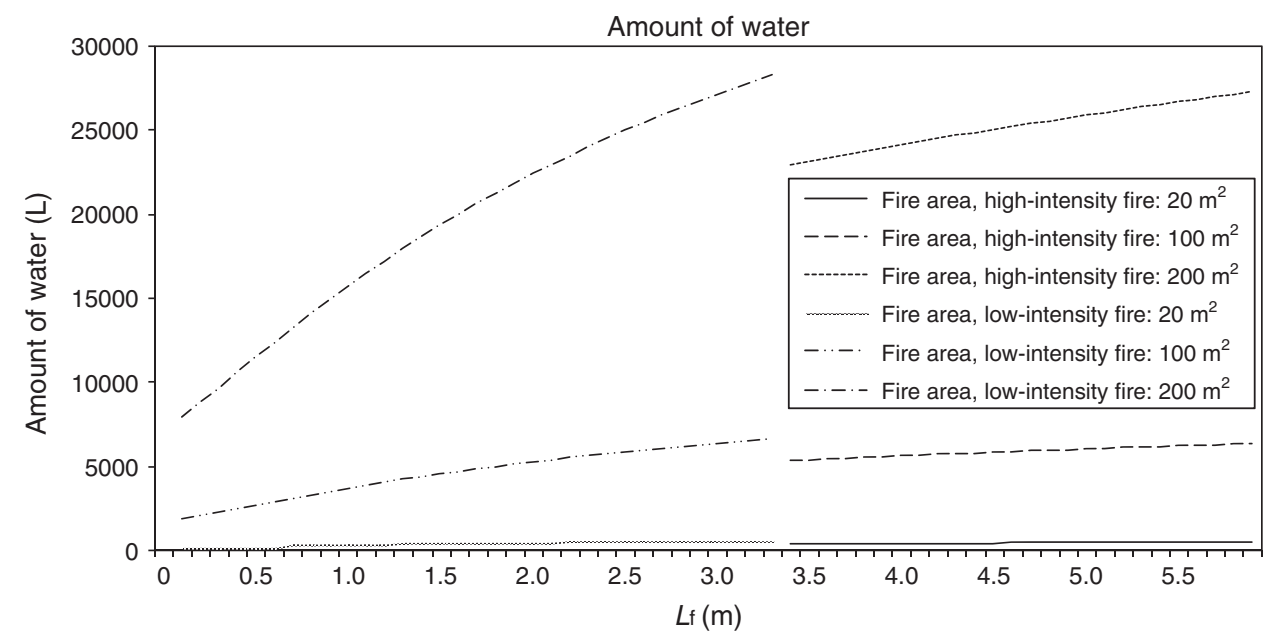

Fig. 4. The amount of water for different fire areas $\left(20,100\right.$ and $\left.200 \mathrm{~m}^{2}\right)$ and fire intensities (low- and highintensity fires) as a function of the flame length.

Table 1. Example of flame lengths of the various fuel models

\begin{tabular}{lc}
\hline Fuel model & Flame length $(\mathrm{m})$ \\
\hline 1 & 1.2 \\
2 & 1.8 \\
3 & 3.6 \\
4 & 5.8 \\
5 & 1.2 \\
6 & 1.8 \\
7 & 1.5 \\
8 & 0.3 \\
9 & 0.8 \\
10 & 1.5 \\
11 & 1.1 \\
12 & 2.4 \\
13 & 3.2 \\
\hline
\end{tabular}

content of $100 \%$ is applicable to fuel models $4,5,6,7,8,9$ and 10).

Fig. 5 shows graphs for fuel models 8 and 9 (low-intensity fires), and 3 and 4 (high-intensity fires), where the water amount is a function of the active combustion area. The depth of the active combustion zone was assumed to be $1 \mathrm{~m}$; this is a rough assumption, as the depth will vary between fuel models.

\section{Validation of the calculations for low-intensity surface fires}

Few studies have been conducted with respect to the amount of water required for a wildfire of a certain size and intensity.

Loane and Gould (1986) presented equations for calculating the depth of retardant required to stop the fire from burning past a treated area for at least $1 \mathrm{~h}$. The equations were validated for heat release rates per unit length of fire front up to $2 \mathrm{MW} \mathrm{m}^{-1}$ and were based on experimental data from aerial drops on fires in various fuels complemented with small-scale experiments and field studies. As the influence of the size of the active combustion zone is not accounted for and as no experimental

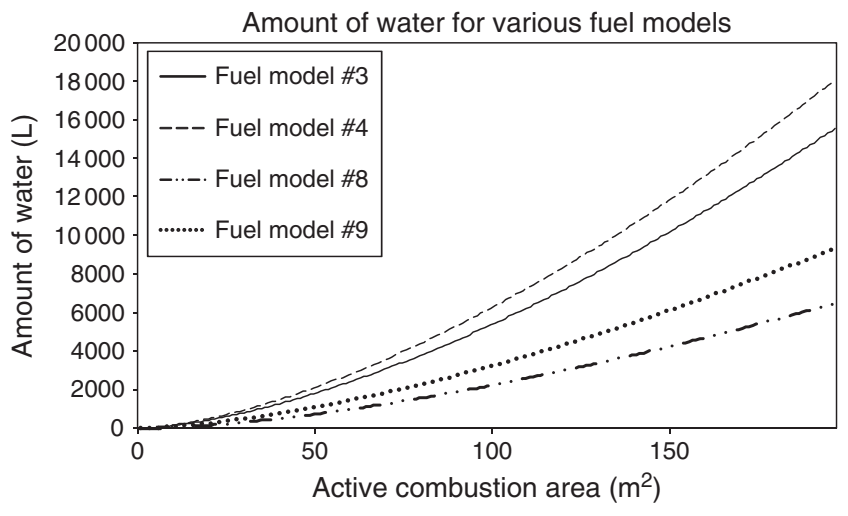

Fig. 5. The amount of water as a function of the active combustion area for fuel models 3 (solid line), 4 (dashed line), 8 (dash/two dots line) and 9 (dotted line).

data were reported in the paper, it is difficult to make any comparisons with calculated theoretical values.

George and Johnson (1990) presented coverage levels of fire suppressant for the 20 different fuel models in the 1978 National Fire Danger Rating System - for aerial application; see Table 2. It is unclear whether the figures presented were based on experimental results or not.

As was the case with the equations of Loane and Gould, it is difficult to make any comparisons with calculated theoretical values as the influence of the size of the active combustion zone is not accounted for and no experimental data were reported in the paper.

Stechishen (1970) conducted experiments where a spray rig with a nozzle arrangement was used to apply water uniformly across a fuel bed. One of the objectives was to investigate the required water application during air-tanker operations. The fuel bed was composed of Pinus resinosa (red pine) needles, including bark platelets, cones and twig fragments; and Abies balsamea (balsam fir) slash beds. The size of the fuel bed was 1.8 by 
$3.6 \mathrm{~m}\left(\sim 6.5 \mathrm{~m}^{2}\right)$. The fuel bed was ignited simultaneously across the full width at the far end. The spray rig travelled perpendicularly to the fire spread direction, across the whole fire front. After reaching the opposite end, the rig and water application stopped. The border between burned and unburned parts of the fuel bed was mapped; the water penetration depths were recorded.

The 34 test fires were permitted to burn for 20 or more minutes after water application stopped to measure how much the fire was retarded. All the tests were in the low-intensity range, i.e. $\sim 350 \mathrm{~kW} \mathrm{~m}^{-1}$.

The results from the tests indicated that comparisons between tests for different fuels were not possible owing to differences in fuel voidage. For example, the amount of air within the Abies balsamea (balsam fir) slash beds was much greater than within those of pine needles. Therefore heat release rates were substantially higher for the balsam fir slash beds, although the water requirements were much lower. Water penetration was greater through the fir slash than through the pine needles. Thus, the water's extinguishing qualities were enhanced in the fir slash case.

Table 2. Coverage levels of fire suppressant for the different fuel models (George and Johnson 1990)

\begin{tabular}{ll}
\hline Coverage level $\left(\mathrm{L} \mathrm{m}^{-2}\right)$ & Fuel model \\
\hline 0.41 & $\mathrm{~A}, \mathrm{~L}, \mathrm{~S}$ \\
0.82 & $\mathrm{C}, \mathrm{H}, \mathrm{P}, \mathrm{U}, \mathrm{E}, \mathrm{R}$ \\
1.23 & $\mathrm{~K}, \mathrm{~F}^{\mathrm{A}}, \mathrm{N}, \mathrm{T}$ \\
1.64 & $\mathrm{G}$ \\
2.46 & $\mathrm{D}, \mathrm{Q}, \mathrm{F}^{\mathrm{A}}$ \\
$>2.46$ & $\mathrm{~B}, \mathrm{I}, \mathrm{J}, \mathrm{O}$ \\
\hline
\end{tabular}

${ }^{\mathrm{A}}$ The coverage level for intermediate brush depends on its stage of curing.
Stechishen and Little (1971) presented another paper evaluating the effectiveness of water during air-tanker operations. For known heat release rates per unit length of fire front, the depths of water required for extinguishment were presented. The following fuels were used in the experiments: red pine needles, twigs and bark; balsam fir slash; Picea glauca (white spruce) slash and Picea mariana (black spruce) slash. The paper contains adequate data for validation against calculated theoretical values and was used in the following validation work.

The experimental set-up and procedure were the same as in Stechishen (1970). In all tests, the flame height was visually noted. In Fig. 6, the flame height for the three fuel types is plotted. As the experiments were either conducted inside a shelter or in the open with an upper wind velocity limit of $0.9 \mathrm{~m} \mathrm{~s}^{-1}$, the flame height was assumed to be equal to the flame length.

In Table 3, several heat release rate values with corresponding water application values (expressed as the water depth) for the red pine needle tests are listed. Only the cases where extinguishment took place within 20 min of water application are given. The heat release rate values were calculated using fuel loading as a criterion, all the combustion was assumed to occur during the passing of the flaming front and no glowing or smouldering was assumed as a conservative assumption; complete combustion was not assumed as the heat of combustion was corrected for moisture content. The fuel moisture content and the flame height according to Fig. 6, corresponding to the relevant heat release rate, are given.

The result of calculating the theoretical amount of water required for the red pine needle test using Eqns 8-9, 14 and 24, and comparing the values with the measured amount of water applied across the active combustion zone, can be seen in Fig. 7. The area of the active combustion zone was calculated using the software tool BehavePlus, producing the rate of heat release per unit area in the active combustion zone and the depth of the active combustion zone (Eqn 16). For the calculations in

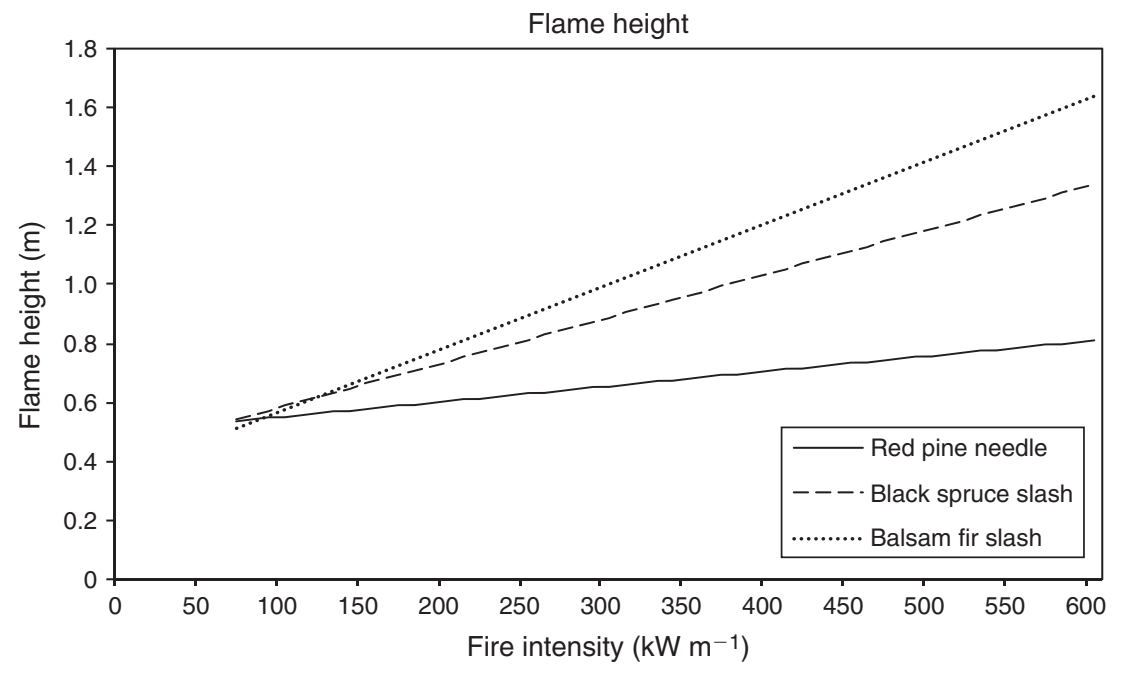

Fig. 6. The flame height as a function of the heat release rate per unit length of fire front for the three different fuel types (Red pine needle (solid line), Black spruce slash (dashed line) and Balsam fir slash (dotted line)) (Stechishen and Little 1971). 
Table 3. The heat release rate values, water application values, flame heights and fuel moisture contents for tests conducted with red pine needles (Stechishen and Little 1971)

\begin{tabular}{|c|c|c|c|c|}
\hline $\begin{array}{l}\text { Test } \\
\text { number }\end{array}$ & $\begin{array}{l}\text { Heat release rate per } \\
\text { unit length of fire front } \\
\qquad\left(\mathrm{kW} \mathrm{m}^{-1}\right)\end{array}$ & $\begin{array}{l}\text { Water } \\
\text { depth } \\
(\mathrm{m})\end{array}$ & $\begin{array}{l}\text { Flame } \\
\text { height } \\
\text { (m) }\end{array}$ & $\begin{array}{c}\text { Fuel moisture } \\
\text { content } \\
(\%)\end{array}$ \\
\hline 1 & 108 & 0.0006 & 0.55 & 13.9 \\
\hline 2 & 63 & 0.0006 & 0.53 & 13.3 \\
\hline 3 & 100 & 0.0006 & 0.55 & 11.8 \\
\hline 5 & 355 & 0.0006 & 0.68 & 10.4 \\
\hline 6 & 321 & 0.0006 & 0.66 & 10.4 \\
\hline 7 & 364 & 0.0006 & 0.69 & 10.3 \\
\hline 9 & 297 & 0.0005 & 0.65 & 10.8 \\
\hline 10 & 284 & 0.0005 & 0.64 & 12.0 \\
\hline 11 & 278 & 0.0004 & 0.64 & 12.1 \\
\hline 15 & 506 & 0.0015 & 0.76 & 8.3 \\
\hline 17 & 628 & 0.0022 & 0.83 & 9.0 \\
\hline 19 & 184 & 0.0007 & 0.59 & 9.4 \\
\hline 23 & 224 & 0.0003 & 0.61 & 10.2 \\
\hline 27 & 170 & 0.0002 & 0.58 & 9.1 \\
\hline 32 & 299 & 0.0005 & 0.65 & 11.7 \\
\hline 36 & 996 & 0.0019 & 1.02 & 12.6 \\
\hline 134 & 123 & 0.0058 & 0.56 & 12.2 \\
\hline 136 & 170 & 0.0008 & 0.58 & 13.7 \\
\hline 137 & 192 & 0.0012 & 0.60 & 12.4 \\
\hline 148 & 242 & 0.0016 & 0.62 & 10.1 \\
\hline 149 & 243 & 0.0018 & 0.62 & 11.3 \\
\hline
\end{tabular}

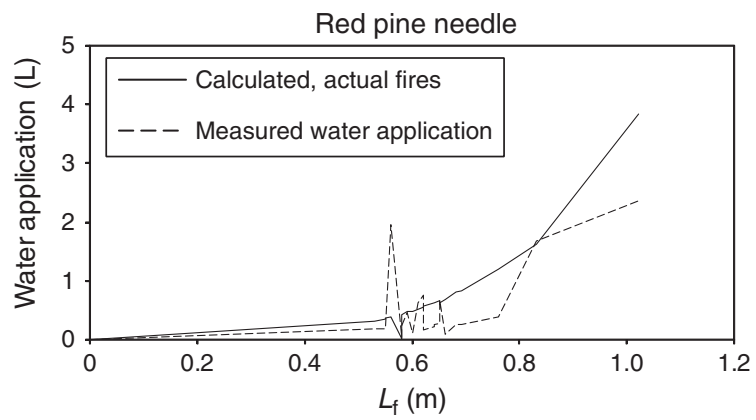

Fig. 7. The calculated water application (solid line) values $v$. the measured values (dashed line) for the red pine needle case.

BehavePlus, the red pine needle bed was assumed to be fuel model 9 (Anderson 1982) and the fuel moisture content was set equal to the 1 -h moisture content. The 10 -h moisture content was assumed to be equal to the 1 -h moisture content plus $1 \%$, and the $100-\mathrm{h}$ moisture content was assumed to be equal to the $1-\mathrm{h}$ moisture content plus $2 \%$.

In a wildfire situation, the depth of the active combustion zone would be determined by visual observation and not through calculations, but as no depths of the active combustion zone were recorded by Stechishen and Little (1971), calculations had to be used in the present paper.

As can be seen in Fig. 7, the calculated water application values match the measured values very well. The value from test 134 clearly deviates from the other values; an explanation could be that this fire burned more deeply and water could not
Table 4. The heat release rate values, water application values, flame heights and fuel moisture contents for tests conducted with balsam fir slash (Stechishen and Little 1971)

\begin{tabular}{lcccc}
\hline $\begin{array}{l}\text { Test } \\
\text { number }\end{array}$ & $\begin{array}{c}\text { Heat release rate per } \\
\text { unit length of fire front } \\
\left(\mathrm{kW} \mathrm{m}^{-1}\right)\end{array}$ & $\begin{array}{c}\text { Water } \\
\text { depth } \\
(\mathrm{m})\end{array}$ & $\begin{array}{c}\text { Flame } \\
\text { height } \\
(\mathrm{m})\end{array}$ & $\begin{array}{c}\text { Fuel moisture } \\
\text { content } \\
(\%)\end{array}$ \\
\hline 102 & 630 & 0.0014 & 1.70 & 14.2 \\
103 & 360 & 0.0009 & 1.13 & 13.7 \\
105 & 649 & 0.0011 & 1.74 & 13.8 \\
106 & 462 & 0.0012 & 1.34 & 13.0 \\
108 & 296 & 0.0008 & 0.99 & 13.8 \\
110 & 187 & 0.0006 & 0.76 & 12.5 \\
111 & 416 & 0.0006 & 1.25 & 10.2 \\
112 & 421 & 0.0009 & 1.26 & 13.2 \\
113 & 344 & 0.0008 & 1.09 & 13.7 \\
114 & 559 & 0.0010 & 1.55 & 16.2 \\
117 & 813 & 0.0013 & 2.08 & 13.9 \\
118 & 334 & 0.0004 & 1.07 & 14.3 \\
120 & 279 & 0.0006 & 0.96 & 13.6 \\
122 & 510 & 0.0010 & 1.44 & 14.9 \\
124 & 272 & 0.0010 & 0.94 & 14.8 \\
125 & 262 & 0.0010 & 0.92 & 15.6 \\
127 & 597 & 0.0012 & 1.63 & 14.7 \\
129 & 526 & 0.0009 & 1.48 & 16.1 \\
132 & 540 & 0.0013 & 1.51 & 16.7 \\
139 & 692 & 0.0015 & 1.83 & 15.8 \\
141 & 763 & 0.0018 & 1.98 & 15.2 \\
143 & 892 & 0.0020 & 2.25 & 15.3 \\
\hline & & & & \\
\hline
\end{tabular}

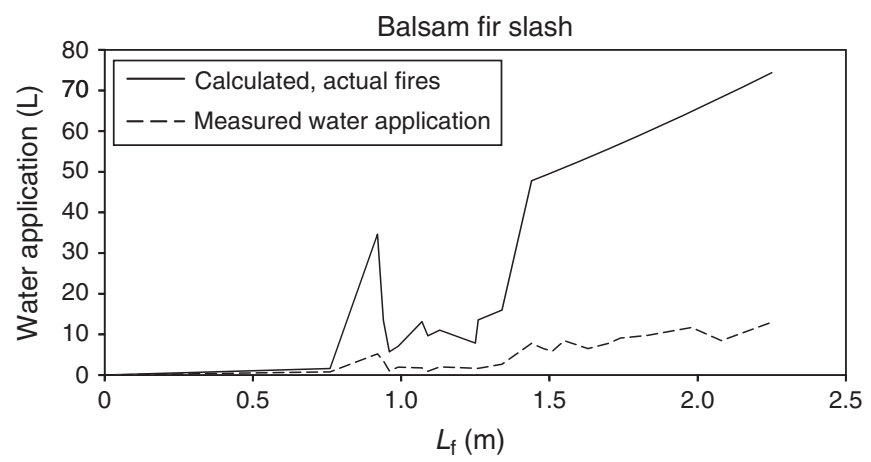

Fig. 8. The calculated water application (solid line) values $v$. the measured values (dashed line) for the Balsam fir slash case.

penetrate the fuel bed down to the base of the bed (Stechishen and Little 1971).

Similarly, in Table 4, several heat release rate values with water application values, flame heights and fuel moisture contents for the balsam fir slash tests, are listed.

The curves for the calculated water application and measured values can be seen in Fig. 8. The balsam fir slash bed was assumed to be fuel model 11 (Anderson 1982) and the fuel moisture content was set equal to the 10-h moisture content. In the cases where BehavePlus predicted a heat release rate per unit area equal to zero or a greater depth than the actual depth of the fuel bed, the area of the active combustion zone was set to the full area of the fuel bed. The calculated water application values 
Table 5. The heat release rate values, water application values, flame heights and fuel moisture contents for tests conducted with black spruce slash (Stechishen and Little 1971)

\begin{tabular}{lcccc}
\hline $\begin{array}{l}\text { Test } \\
\text { number }\end{array}$ & $\begin{array}{c}\text { Heat release rate per } \\
\text { unit length of fire front } \\
\left(\mathrm{kW} \mathrm{m}^{-1}\right)\end{array}$ & $\begin{array}{c}\text { Water } \\
\text { depth } \\
(\mathrm{m})\end{array}$ & $\begin{array}{c}\text { Flame } \\
\text { height } \\
(\mathrm{m})\end{array}$ & $\begin{array}{c}\text { Fuel moisture } \\
\text { content } \\
(\%)\end{array}$ \\
\hline 151 & 228 & 0.0013 & 0.78 & 14.8 \\
152 & 136 & 0.0008 & 0.64 & 14.9 \\
153 & 209 & 0.0008 & 0.75 & 14.7 \\
154 & 326 & 0.0008 & 0.93 & 15.4 \\
156 & 427 & 0.0014 & 1.08 & 17.4 \\
\hline
\end{tabular}

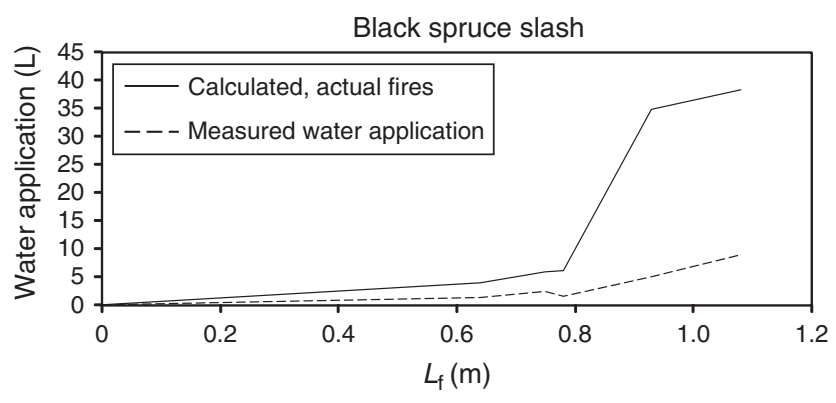

Fig. 9. The calculated water application values (solid line) $v$. the correlated measured values (dashed line) for the Black spruce slash case.

were considerably higher than the corresponding measured values for balsam fir slash, especially for larger flame lengths. Common to all the cases where the calculated value was considerably higher than the measured value was that the calculated depth of the active combustion zone was deeper than the actual depth of the fuel bed. In slash fires, the flame lengthto-depth ratio is lower than for fires involving fine fuels, and a question here is how well Eqn 3 relates to the actual depth of a slash fire. An explanation for the large differences could be the inability of Eqns 3 and 16 to predict the fire depth in balsam fir slash, or the answer may be a weakness in the BehavePlus software.

Furthermore, the methodology is dependent on the ability of Byram's and Thomas' equations to properly predict the relationship between flame length and heat release rates per unit length of fire front for laminar flames as well as turbulent flames. The question here is whether the turbulent flames are properly predicted using Byram's and Thomas' equations.

In Table 5, several heat release rate values with water application values, flame heights and fuel moisture contents for black spruce slash tests are listed.

The curves of the calculated water application and the measured values can be seen in Fig. 9. The black spruce slash bed was assumed to be fuel model 11 (Anderson 1982) and the fuel moisture content was set equal to the 10-h moisture content The calculated water application values were generally higher than the measured values for black spruce slash for larger flame lengths. The same observation as for the balsam fir slash case can be made, i.e. where the calculated value was considerably higher than the measured value it as also found that the calculated depth of the active combustion zone was deeper than the actual depth of the fuel bed. Explanations for the large differences could be the same as for the balsam fir slash. However, as the number of experiments using black spruce slash was very low (five experiments), it is difficult to draw further conclusions.

Stechishen and Little used fuel loading as the criterion to obtain heat release rates. It is unfortunate that the flame length was not used instead, as there were inconsistencies in the heat release rate due to the difficulty in predicting the weight of fuel consumed. This would not be an issue if the flame length had been used.

A drawback when comparing experimental results from water application tests corresponding to air-tanker operations is the fact that the application will differ when comparing with water applied on the ground by firefighters using nozzles. In the first case, the water will be applied vertically and will penetrate the fire plume. In the latter case, the water will be applied mostly horizontally and will not penetrate the fire plume to any large extent.

Stechishen and Little (1971) concluded that using only the heat release rate as a predictor for water requirements will not give satisfactory results, as the structure and size of the fuel play an important role in water penetration into the fuel. For example, the amount of air space in the balsam fir slash beds was much greater than that in red pine needle fuels. Therefore, although heat release rates were substantially greater for the balsam fir slash beds, water requirements were much lower because water penetration was greater through the fir slash. The greater difference between calculated values and measured values for balsam fir slash compared with red pine needles illustrates the importance of including specific fuel structure characteristics when determining the amount of water required.

In the validation work ,the depth of the active combustion zone was determined using BehavePlus. There are uncertainties whether the most appropriate fuel model was selected. In a wildfire situation, the depth of the active combustion zone would be determined by visual observation and not through calculations, eliminating this uncertainty.

\section{Sensitivity analysis}

Throughout this paper, several rough assumptions have been made owing to the lack of suitable values available in the literature. A sensitivity analysis was conducted to evaluate how the input parameters influence the output parameter. See Table 6 for the resulting output.

When studying the variance values, high output values and swing values, it was noted that $\eta_{\text {water }}, c_{\mathrm{p}}$ and $L_{\mathrm{v} \text {,water }}$ present the highest variance values; this is due to the high output values when the input value approaches zero. Among the other input values, it can be seen that the fire area, the convective heat transfer coefficient, $\Delta H_{\mathrm{R}, \mathrm{O}_{2}}, Y_{\mathrm{O}_{2}}, c_{\mathrm{p}}$ and $L_{\mathrm{v} \text {,water }}$ have the largest effect on the output. In the case of the fire area and convective heat transfer coefficient, there are considerable uncertainties in the input values and also in the resulting output value. 
Table 6. Resulting data for the sensitivity analysis, in which the amount of water value was evaluated

\begin{tabular}{|c|c|c|c|c|c|c|c|c|}
\hline \multirow[t]{2}{*}{ Input variable } & \multicolumn{3}{|c|}{ Input values } & \multicolumn{3}{|c|}{ Output value (amount of water) } & \multirow[t]{2}{*}{ Swing } & \multirow{2}{*}{$\begin{array}{c}\text { Variance } \\
(\%)\end{array}$} \\
\hline & Low & Base & High & Low & Base & High & & \\
\hline$\varepsilon$ & 0.0 & 0.6 & 1.2 & 1.9477 & 1.7513 & 1.5549 & 0.3928 & 0.0 \\
\hline$T_{\text {fuel }}$ & 0.0 & 588 & 1176 & 2.5659 & 1.7513 & -1.994 & 4.5599 & 0.0 \\
\hline Radiative component & 0.0 & 0.27 & 0.54 & 1.2423 & 1.7513 & 2.2602 & 1.0179 & 0.0 \\
\hline$L_{\mathrm{v}}$ & 0.0 & 1800 & 3600 & 2.6298 & 1.7513 & 0.8727 & 1.7571 & 0.0 \\
\hline$H$ & 0.0 & 0.02 & 0.04 & 0.3125 & 1.7513 & 3.1900 & 2.8775 & 0.0 \\
\hline$\Delta \mathrm{H}_{\mathrm{R}, \mathrm{O}_{2}}$ & 0.0 & 13980 & 27960 & 0.0088 & 1.7513 & 2.9285 & 2.9197 & 0.0 \\
\hline$Y_{\mathrm{O}_{2}}$ & 0.0 & 0.23 & 0.46 & 0.0088 & 1.7513 & 2.9285 & 2.9197 & 0.0 \\
\hline$A_{\text {fire }}$ & 0.0 & 0.78 & 1.56 & $1.747 \times 10^{-30}$ & 1.7513 & 4.8878 & 4.8878 & 0.0 \\
\hline$\Delta H_{\mathrm{c}}$ & 0.0 & 17900 & 35800 & -81.269 & 1.7513 & 2.4468 & 83.7159 & 0.0 \\
\hline$\phi$ & 0.0 & 0.3 & 0.6 & -81.269 & 1.7513 & 2.4468 & 83.7159 & 0.0 \\
\hline$\eta_{\text {water }}$ & 0.0 & 0.5 & 1.0 & $2.2917 \times 10^{19}$ & 1.7513 & 1.1301 & $2.2917 \times 10^{19}$ & 20.18 \\
\hline$c_{\mathrm{p}}$ & 0.0 & 1.0 & 2.0 & $3.2143 \times 10^{19}$ & 1.7513 & 0.8801 & $3.2143 \times 10^{19}$ & 39.71 \\
\hline$L_{\mathrm{v}, \text { water }}$ & 0.0 & 2640 & 5280 & $3.2306 \times 10^{19}$ & 1.7513 & 0.8756 & $3.2306 \times 10^{19}$ & 40.11 \\
\hline
\end{tabular}

\section{Conclusions}

Theoretical calculations of the amount of water required to extinguish a fire in various fuel types have been carried out and compared with results from low-intensity surface fire experiments. The method presented uses physical relationships to determine the required amount of water as a function of the heat release rate per unit length of fire front. The method uses the Fire Point Theory to determine the critical water flow rate for various flame lengths. The time duration of the water application was calculated using equations from previous statistical studies.

The results were tested against experimental tests. The calculated water application values matched the experimental values very well in the case of red pine needles. This clearly shows the feasibility of the method for the problem when calculating the required amount of water for a fire area using easily distinguished input parameters.

The calculated water application values did not match the experimental values well in the cases of balsam fir slash and black spruce slash for larger flame lengths. In slash fires, the flame length-to-depth ratio is lower than for fires involving fine fuels, and a possible explanation for the difference between calculated and measured values could be the inability of Byram's equation to predict the fire depth in balsam fir slash and black spruce slash. The possible inability to predict the depth of a fire in slash fuel adds to the uncertainties of the output value, as the fire area was found in a sensitivity analysis to have a very large effect on the output value.

The method must be developed further in order also to account for fuel factors and not rely heavily on the heat release rate per unit length of fire front.

There is also the question whether the turbulent flames are properly predicted using Byram's and Thomas' equations, affecting the calculated water application value.

To further validate the method, the following work is recommended: the method should be applied to fire experiments where the water is applied horizontally, fuel parameters such as compaction and surface area/volume ratio should be included in future studies; higher wind conditions, tilting flames and crown fires should also be included and a statistical study performed to incorporate operational aspects when applying water on a wildfire.

Better suited values - such as ignition temperature or fuel emissivity - should be elaborated as approximate assumptions were made with respect to appropriate fire values in the paper. The approximate assumptions were made owing to the lack of suitable values in the literature and the paper was mainly focussed on describing the methodology.

\section{Nomenclature}

$A$, flame angle

$A_{\text {fire, }}$, fire area

$B_{\mathrm{cr}}$, B number at extinguishment

$c_{\mathrm{p}}$, specific heat

$D$, depth of the active combustion zone

$f$, heat release fraction transferred back to the fuel surface by convection and radiation

$g$, acceleration due to gravity

$H$, heat of combustion

$H_{\mathrm{f}}$, height of the flame tip

$\Delta H_{\mathrm{c}}$, effective heat of combustion

$\Delta H_{\mathrm{R}, \mathrm{O}_{2}}$, heat of combustion per unit mass of oxygen consumed

$H_{\mathrm{t}}$, forest canopy height

$h$, convective heat transfer coefficient

$h_{\mathrm{f}}$, flame height

$I$, heat release rate per unit length of fire front

$I_{\mathrm{R}}$, heat release rate per unit area in the active combustion zone

$L_{\mathrm{f}}$, flame length

$L_{\mathrm{v}}$, heat of gasification of the fuel

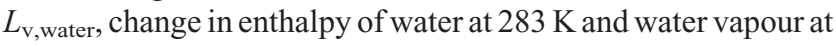
$373 \mathrm{~K}$

$\dot{m}^{\prime \prime}$, mass burning rate per unit fuel area

$\dot{m}_{\text {cr }}^{\prime \prime}$, critical mass loss rate

$\dot{m}_{\text {water,cr }}^{\prime \prime}$, critical water application rate

$\dot{m}_{\text {water,cr, } 0}^{\prime \prime}$, critical water application rate with no external heat flux

$\dot{Q}_{\mathrm{r}}^{\prime}$, radiative component per unit length of fire front of the total

heat release rate

$\dot{q}_{\text {conv }}^{\prime \prime}$, convective heating per unit area 
$\dot{q}_{\mathrm{E}}^{\prime \prime}$, externally applied heat flux

$\dot{q}_{\mathrm{E}, 0}^{\prime \prime}$, minimum heat flux for sustaining a fire

$\dot{q}_{\mathrm{f}}^{\prime \prime}$, incident flame radiation per unit area

$\dot{q}_{\mathrm{L}}^{\prime \prime}$, heat loss from the surface

$\dot{q}_{\mathrm{L}, \mathrm{rad}}^{\prime \prime}$, radiative heat loss

$\dot{q}_{\mathrm{L}, \mathrm{conv}}^{\prime \prime \prime}$, convective heat loss

$\dot{q}_{\text {water }}^{\prime \prime}$, heat loss due to the vaporisation of water

$r$, rate of spread

$\Delta T$, temperature difference between fuel surface and surrounding air

$T_{\mathrm{a}}$, ambient temperature

$T_{\text {fuel }}$, fuel surface temperature

$T_{\mathrm{g}}$, temperature of the gas

$t$, time

$U$, mean horizontal wind speed

$U_{\mathrm{c}}$, wind speed at the top of the forest canopy

$U_{10}$, wind speed at a height of $10 \mathrm{~m}$ in the open

$w$, mass of the available fuel per unit area

$Y_{\mathrm{O}_{2}}$, oxygen mass fraction

$\alpha$, tilt angle

$\varepsilon$, emissivity

$\eta_{\text {water }}$, efficiency of water application

$\phi$, fractional convective heat loss from the flame

$\sigma$, Stefan-Boltzmann constant

$\varphi$, view factor

$\tau$, atmospheric transmissivity

\section{References}

Albini FA (1966) A physical model for fire spread in brush. In 'Eleventh International Symposium on Combustion', 14-20 August 1966, Berkeley, CA. pp. 553-560. (The Combustion Institute: Pittsburgh, PA)

Albini FA (1976) Estimating wildfire behavior and effects. USDA Forest Service, Intermountain Forest and Range Experiment Station, General Technical Report INT-30. (Ogden, UT)

Albini FA (1981) A model for the wind-blown flame from a line fire. Combustion and Flame 43, 155-174. doi:10.1016/0010-2180(81) 90014-6

Albini FA (1985) A model for fire spread in wildland fuels by radiation. Combustion Science and Technology 42, 229-258. doi:10.1080/ 00102208508960381

Alexander ME (1982) Calculating and interpreting forest fire intensities Canadian Journal of Botany 60, 349-357. doi:10.1139/B82-048

Alexander ME (2000) Fire behaviour as a factor in forest and rural fire suppression. New Zealand Fire Service Commission and The National Rural Fire Authority Forest Research Bulletin Number 197, Forest and Rural Fire Scientific and Technical Series Report Number 5. (Wellington, New Zealand)

Anderson HE (1982) Aids to determining fuel models for estimating fire behavior. USDA Forest Service, Intermountain Forest and Range Experiment Station, General Technical Report INT-122. (Ogden, UT)

Andrews PL, Rothermel RC (1982) Charts for interpreting wildland fire behaviour characteristics. USDA Forest Service, Intermountain Forest and Range Experiment Station, General Technical Report INT-131. (Ogden, UT)

Baldwin R (1970) The use of water in the extinguishment of fires by brigades. Fire Research Station, Borehamwood Fire Research Note 803. (Borehamwood, England)

Beyler C (1992) A unified model of fire suppression. Journal of Fire Protection Engineering 4, 5-16. doi:10.1177/104239159200400102
Butler BW, Finney MA, Andrews PL, Albini FA (2004) A radiation-driven model for crown fire spread. Canadian Journal of Forest Research $\mathbf{3 4}$ 1588-1599. doi:10.1139/X04-074

Byram GM (1959) Combustion of forest fuels. In 'Forest Fire: Control and Use'. (Ed. KP Davis) (McGraw-Hill Book Company Inc.: New York)

Chandler C, Cheney P, Thomas P, Trabaud L, Williams D (1983) 'Fire in Forestry, Volume 1. Forest Fire Behavior and Effects.' (Wiley: Chichester, UK)

Douglas DR (1973) Initial attack standards. Australian Forestry Council Research working group number 6, July 1973. Newsletter Number 4. (Canberra, ACT)

George CW, Johnson GM (1990) Developing air tanker performance guidelines. USDA Forest Service, Intermountain Research Station, General Technical Report INT-268. (Ogden, UT)

Johnson VJ (1982) The dilemma of flame length and intensity. USDA Forest Service, Fire Management Notes, Fall, Vol. 43, Number 4, pp. 3-7. (Washington, DC)

Kung HC, Hill JP (1975) Extinguishment of wood crib and pallet fires. Combustion and Flame 24, 305-317. doi:10.1016/0010-2180(75) 90164-9

Loane IT, Gould JS (1986) 'Project Aquarius. Aerial Suppression of Bushfires. Cost-Benefit Study for Victoria' (National Bushfire Research Unit, CSIRO Division of Forest Research: Canberra, ACT)

Madrigal J, Hernando C, Guijarro M, Díez C, Marino E (2009) Evaluation of forest fuel flammability and combustion properties with an adapted mass-loss calorimeter device. Journal of Fire Sciences 27, 323-342. doi:10.1177/0734904109102030

Malbi LA (2001) Modeling backing fires in California grassland fuels. PhD dissertation, University of California-Berkeley, Berkeley, CA.

O’Dougherty MJ, Young RA (1965) The performance of automatic sprinkler systems: Part II - The effect of water application rate and fire size on the extinguishment of wooden crib fires. Fire Research Station, Borehamwood Fire Research Note \#603. (Borehamwood, UK)

Rasbash DJ (1975) Relevance of Fire Point Theory to the Assessment of Fire Behaviour of Combustible Materials. University of Edinburgh report. (Edinburgh, UK)

Rasbash DJ (1986) The extinguishment of fire with plain water: a review Fire Safety Science 1, 1145-1163. doi:10.3801/IAFSS.FSS.1-1145

Rothermel RC (1972) A mathematical model for predicting fire spread in wildland fuels. USDA Forest Service, Intermountain Forest and Range Experiment Station, Research Paper INT-115. (Ogden, UT)

Rothermel RC (1991) Crown fire analysis and interpretation. In 'Proceedings of 11th Conference on Fire and Forest Meteorology', 16-19 April 1991, Missoula, MT. (Eds PL Andrews, DF Potts) pp. 253-263. (Society of American Foresters: Bethesda, MD)

Santoni P-A, Morandini F, Barboni T (2010) Steady and unsteady fireline intensity of spreading fires at laboratory scale. The Open Thermodynamics Journal 4, 212-219.

Silvani X, Morandini F (2009) Fire spread experiments in the field: temperature and heat fluxes measurements. Fire Safety Journal 44, 279-285. doi:10.1016/J.FIRESAF.2008.06.004

Sneeuwjagt RJ, Frandsen WH (1977) Behavior of experimental grass fires vs. predictions based on Rothermel's fire model. Canadian Journal of Forest Research 7, 357-367. doi:10.1139/X77-045

Spalding DB (1955) Some fundamentals of combustion. In 'Gas Turbine Series'. pp. 62, 63, 126. (Butterworth Scientific Publications; London)

Stechishen E (1970) Measurement of the effectiveness of water as a fire suppressant. Canadian Forestry Service, Forest Fire Research Institute, Information Report FF-X-23. (Ottawa, ON)

Stechishen E, Little EC (1971) Water application depths required for extinguishment of low-intensity fires in forest fuels. Canadian Forestry Service, Forest Fire Research Institute, Information Report FF-X-29. (Ottawa, ON) 
Tamanini F (1976) The application of water sprays to the extinguishment of crib fires. Combustion Science and Technology 14, 17-23. doi:10.1080/ 00102207608946742

Tangren CD (1976) The trouble with fire intensity. Fire Technology 12, 261-265. doi:10.1007/BF02624803

Tewarson A (2002) Generation of heat and chemical compounds in fires. In 'The SFPE Handbook of Fire Protection Engineering'. (Eds PJ DiNenno, D Drysdale, CL Beyler, WD Walton, RLP Custer, JR Hall, JM Watts) pp. 3.82-3.161. (National Fire Protection Association: Quincy, MA)

Thomas PH (1957) A note on the extinguishment of very large fires. Fire Research Station, Borehamwood Fire Research Note 245. (Borehamwood, England)

Thomas PH (1963) The size of flames from natural fires. In 'Proceedings of the 9th International Symposium on Combustion', 27 August-1 September 1963, Ithaca, NY, pp. 844-859. (The Combustion Institute: Pittsburgh, PA)

Thomas PH (1971) Rates of spread of some wind-driven fires. Forestry 44, 155-175. doi:10.1093/FORESTRY/44.2.155
Tihay V, Santoni P-A, Simeoni A, Garo J-P, Vantelon J-P (2009) Skeletal and global mechanisms for the combustion of gases released by crushed forest fuels. Combustion and Flame 156, 1565-1575. doi:10.1016/ J.COMBUSTFLAME.2009.05.004

Torero JL, Simeoni A (2010) Heat and mass transfer in fires: scaling laws, ignition of solid fuels and application to forest fires. The Open Thermodynamics Journal 4, 145-155.

Van Wagner CE (1968) Fire behaviour mechanisms in a red pine plantation: field and laboratory evidence. Canada Department of Forestry and Rural Development, Forestry Branch, Petawawa Forest Experiment Station, Departmental Publication Number 1229. (Chalk River, ON)

Van Wagner CE (1977) Conditions for the start and spread of crown fire. Canadian Journal of Forest Research 7, 23-34. doi:10.1139/X77-004

Weber RO (1989) Analytical models for fire spread due to radiation. Combustion and Flame 78, 398-408. doi:10.1016/0010-2180(89) 90027-8 